\title{
MAKALAH
}

PROBLEMATIKA AKIDAH DI ERA GLOBALISASI

DOSEN MENGAMPU: SUPRIADI HAMID., S.E.I., M.E.I.

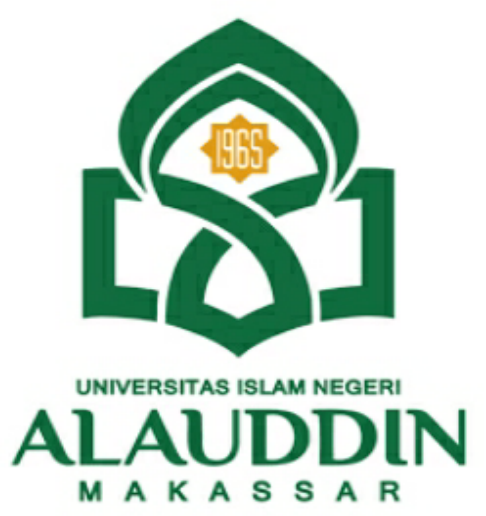

DISUSUN OLEH

KELAS PSY-A

NUR AMALIA DAUD Nim: 90500121011

\author{
PERBANKAN SYARIAH \\ FAKULTAS EKONOMI DAN BISNIS \\ UNIVERSITAS ISLAM NEGERI UIN ALAUDDIN MAKASSAR \\ $2021 / 2022$
}


KATA PENGANTAR

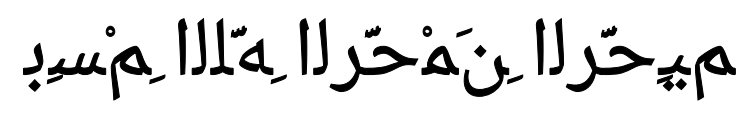

Puji syukur kami panjatkan kehadirat Allah swt karena atas limpahan karunia, rahmat, dan hidayah-Nya yang berupa kesehatan, sehingga makalah yang berjudul "Problematika Akidah Di Era Globalisasi" dapat terselesaikan. makalah ini disusun sebagai tugas matakuliah akidah akhlaq, kami berusaha menyusun makalah ini dengan segala kemampuan, namun kami menyadari bahwa makalah ini masih banyak memiliki kekurangan baik dari segi penulisan maupun segi penyusunan, oleh karena itu kritik dan saran yang bersifat membangunkan, kami terima dengan senang hati demi perbaikan makalah selanjutnya. Semoga makalah ini bisa memberikan manfaat bagi para pembacanya, atas perhatian dan kesempatan yang diberikan untuk membuat makalah ini kami ucapkan terimakasih.

Samata, 2 Desember 2021

Penulis

Nur Amalia Daud 
DAFTAR ISI

Sampul _. _ _

Kata pengantar ___

Daftar isi _ _

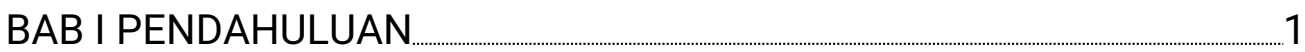

A. Latar Belakang ___._. 1

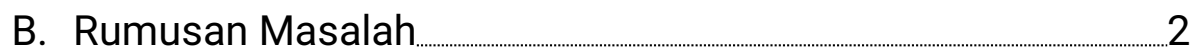

C. Tujuan 2

BAB II PEMBAHASAN

A. Pengertian Akidah Dan Globalisasi $\quad 2$

B. Pengearuh Globalisasi Terhadap Akidah Seseorang $\quad 5$

C. Pentingnya Akidah Di Era Globalisasi $\quad 5$

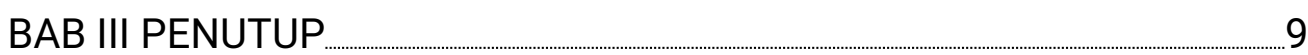

A. Kesimpulan $\quad 9$

B. Saran 9

DAFTAR PUSTAKA 10 


\section{BAB I}

\section{PENDAHULUAN}

\section{A. Latar Belakang}

Di era globalisasi yang dikaitkan dengan proses terbentuknya sistem organisasi serta komunikasi seluruh masyarakat yang ada di dunia dengan tujuan untuk mengikuti sistem dan aturan atau kaidah tertentu yang pada dasarnya memiliki kesamaan.Pada umumnya, arti globalisasi juga erat kaitannya dengan proses sesuatu hal yang mendunia. Hal tersebut dapat berupa informasi, gaya hidup, pemikiran, budaya,hingga teknologi. Dalam proses globalisasi, tentu saja terdapat banyak hal yang menjadi faktor pendorongnya. Beberapa di antaranya dapat disebabkan oleh infrastruktur telekomunikasi, kemajuan transportasi, kemajuan teknologi, pertukaran kebudayaan, dan lain sebagainya.

Karena dengan adanya teknologi terbukanya komunikasi dan informasi memudahkan manusia mendapatkan informasi-informasi aktual dengan cepat dan hanya sedikit hambatan. Perkembangan teknologi ini selain mempunyai manfaat ternyata membawa imbas negatif yang disebabkan oleh budaya asing yang menyesatkan, sehingga menimbulkan kemerosotan norma-norma dalam kehidupan masyarakat. Kebobrokan moral, penyakit rohani, serta bentuk penyimpangan lainnya kini telah merebak dalam masyarakat Indonesia, khususnya generasi muda. Mereka lebih mementingkan urusan duniawi daripada urusan akhirat. 2 Contoh penyimpangan itu adalah: perjudian yang merajalela, perampokan, pencurian, serta pergaulan bebas. Disamping itu, bentuk penyimpangan yang sangat meresahkan bangsa Indonesia adalah 
adanya barang haram berupa narkoba. Barang ini selain dilarang oleh agama Islam merupakan salah satu penyebab rusaknya akhlak, khususnya ganerasi muda penerus bangsa.

C. Rumusan Masalah

Berdasarkan latar belakang yang telah dikemukakan diatas, maka adapun masalah masalah yang akan dibahas dalam makalah ini adalah sebagai berikut:

1. Apa pengertian dari akidah dan globalisasi ?

2. Apa pengaruh globalisasi terhadap akidah seseorang?

3. Apa pentingnya akidah di era globalisasi ?

D. Tujuan

Adapun tujuan yang akan dibahas dalam makalah ini adalah sebagai berikut:

1. Untuk mengetahui pengertian dari akidah dan globalisasi

2. Untuk mengetahui pengaruh globalisasi terhadap akidah seseorang

3. Untuk mengetahui pentingnya akidah di era globalisasi 
BAB II

\section{PEMBAHASAN}

A. Pengertian Akidah Dan Globalisasi

\section{Pengertian Akidah}

Akidah adalah kepercayaan yang bersih dari kebimbangan dan keraguan dimana hati membenarkannya sehingga timbullah ketenangan jiwa. Sedangkan pengertian lain dari aqidah adalah kepercayaan kepada Allah yang Maha Esa.

Akidah secara umum adalah kepercayaan, keimanan, keyakinan Secara mendalamdan benar lalu merealisasikannya dalam perbuatannya. Sedangkan aqidah dalam agama Islam berarti percaya sepenuhnya kepada ke-Esa-an Allah, dimana Allah-lah pemegang kekuasaan tertinggi dan pengatur atas segala apa yang ada di jagad raya.

Akidah diibaratkan sebagai pondasi bangunan. Sehingga aqidah harus dirancang dan dibangun terlebih dahulu dibanding bagian-bagian lain. Aqidah pun harus dibangun dengan kuat dan kokoh agar tidak mudah goyah yang akan menyebabkan bangunan menjadi runtuh. Bangunan yang dimaksud disini adalah

Islam yang benar, menyeluruh, dan sempurna. Aqidah merupakan misi yang ditugaskan Allah untuk semua Rasul-Nya, dari pertama sampai dengan yang terakhir. Aqidah tidak dapat berubah karena pergantian nama, tempat, atau karena perbedaan pendapat suatu golongan.

2. Pengertian Globalisasi

Globalisasi adalah proses mendunianya suatu hal sehingga batas antara negara menjadi hilang. Globalisasi didukung oleh berbagai faktor, seperti perkembangan teknologi, transportasi, ilmu pengetahuan, telekomunikasi, dan sebagainya yang 
lemudian berpengaruh pada perubahan berbagai aspek kehidupan dalam masyarakat.

B. Pengearuh Globalisasi Terhadap Akidah Seseorang

Globalisasi telah memengaruhi beberapa keadaan umat Islam sekarang ini, seperti berikut:

1. Pola pikir yang sekuler

Globalisasi ternyata ada juga membawa manfaat bagi membuka cakrawala berfikir yang sangat luas dan dinamis, karena semua khazanah keilmuan terbuka lebar dibumi ini serta dapat dikomunikasikan kepada siapa saja melalui email, facebook, internet dan perpustakaan digital. Dimasa kini seorang dosen dan guru akan menyampaikan kuliah atau pelajarannya lewat internet, telecomfrens, sehingga boleh jadi seorang mahasiswa atau pelajar tidak mesti duduk dalam ruangan kuliah, mereka boleh dirumah, warung kopi dan dilapangan terbuka untuk mendengarkan kuliah sang dosen

Belajar diera globalisasi ini pula dapat menimbulkan cara berfikir yang skuler dan lebral, karena semakin derasnya arus berfikir Barat yang sekuler dan lebral itu menebus fikiran, jiwa dan emosi para mahasiswa dan remaja umat Islam. Berfikir sekuler dan liberal, merupakan akibat yang tidak terelakkan dari proses modernisasi bangsa. Sekularisasi tanpa modernisasi tak ubahnya bagaikan seperti mata uang yang tidak mungkin dipisahkan satu sama lain. Oleh karena itu, dalam diskursus ilmu sosial atau sosiologi ada sebuah teori terenal yang mengatakan bahwa, makin maju suatu masyarakat, maka semakin menurun komitmen mereka pada agama. "Maju" disini maksudnya adalah "Modern".

Fenomena budaya dan agama yang berkembang di Barat justru dijadikan contoh oleh sebahagian umat Islam di Indonesia, sehingga mengamalkan ajaran 
Islam yang bebas dan sekuler. Secara bebas maksudnya adalah yang mengamalkan Islam secara parsial dan menurut hasil pemikiran semata serta mengikuti kehendak sendiri. Dewasa ini ada wacana agama universal yaitu mengamalkan ajaran Islam menurut situasi dan kondisi, sehingga muncul pengamalan shalat menggunakan bahasa Indonesia, melaksanakan haji tidaj mesti ke Makkah sehingga boleh dilakukan di Indonesia.rakaat shalat boleh ditambah dan berzikir (as-shalatu li zikri) hanya dengan eling (ingat) kepada Allah. Terlalu banyak dikurangi berdasarkan keperluan, dan shalat tidak perlu dikerjakan secara fisik tetapi cukup penyimpangan ajaran Islam yang dilakukan oleh sebagian umat Muslim karena terpengaruh oleh budaya barat.

\section{Memicu Radikalisme Dan Sampalan}

Sekarang ini telah muncul faham radikalisme agama baik dilakukan oleh umat Islam maupun umat non Islam. Faham ini tentu memiliki alasan tersendiri bagi mereka dengan mengatas namakan jihad fi sabilillah dengan tujuan memerangi kejahatan dan oknum pemerintah yang merusak Islam. Alasan ini memang bersumber dari Al-quran yang memerintahkan umat Islam berjuang (jihad) dijalan Allah dengan nyawa, dengan harta (Q.S. 9:20). Pada masa Rasulullah Saw. jihad seperti inilah yang dilakukan oleh pejuang Islam dan para sahabat Nabi pada masa itu. dengan musuhnya yang sangat nyata dan jelas yaitu kafir dan musyrikin Quraisy, sehingga mereka mengangkat senjata melakukan perang besar besaran seperti perang Badar, Uhud, Handaq, dan lainnya. Jihad semacam ini wajib dilakukan karena atas perintah Allah Swt. dan Rasul-Nya.

Lebih-lebih lagi di Indonesia yang multi etnik dan agama yang memerlukan kearifan dari umat Islam yang mayoritas, sehingga dapat melindungi dan bekerja sama dengan umat non Islam mesti melindungi umat non Muslim 
sepanjang mereka tidak mengganggu ajaran Islam dan mengusir umat Islam dari negeri sendiri. Kenyataan ini memang sangat factual terjadi dinegeri ini, yang melecehkan nabi Muhammad Saw dengan karikatur, menghina kehidupannya, menghilangkan beberapa ayat suci Al-quran, mempelesetkan ajaran Islam, dan melakukan sinktritisasi. Kristenisasi, Yahudisasi, terhadap umat Islam banyak lagi kejadian spektakuler terhadap umat Islam yang dapat melecehkan Islam. Dalam banyak kasus ini, pemerintah kurang mampu memberikan penyelesaian yang kurang adil dan memuaskan bagi umat Islam, maka tidak heran para militant umat Islam melakukan perlawanan dengan jihad yang mereka pahami sendiri, bahwa menegakkan ajaran Allah dibumu adalah kewajiban agama dan tidak memperdulikan orang lain. Bom Bali misalnya dilakukan para mujahid yang mengatas namakan Muslim karena dipicu oleh kegiatan yang mengarah kepada demoralisasi merusak bangsa. Bom di hotel Mrihot di Jakarta tempo dulu, juga dipicu oleh dendam mereka terhadap Amerika Serikat yang senantiasa mendiskriclitkan umat Islam dengan terorisme. Dewasa ini muncul pula gerakan radikal Islam yang bernama Islamic State of Iraq and Syiria (ISIS) yang bertentangan dengan ajaran Islam, semua elemen umat Islam di Indonesia, baik dari kalangan pemerintah, MUI dan organisasi masyarakat Islam melarang keberadaan gerakan ini dapat merusak sendi-sendi kehidupan umat beragama serta merong-rong bangsa Indonesia yaitu pancasila, UUD 1945, Bhineka Tunggal Ika dan NKRI. Meskipun gerakan tersebut ada di Timur Tengah tetapi, gerakan ini dapat memicu radikalisme di Indonesia kerea terdapat puluhan dunia luar yang ditiru dan disikapi oleh sebahagian kecil bangsa Indonesia masa kini.

Selain itu muncul juga secara internal aliran-aliran Islam yang sempalan yang pada awal Islam bersumber dari pemahaman teologi yang berbeda sudut 
pandang sehingga sesama umat Islam saling kafir mengkafirkan. Akibat itu ditambah pula dengan suasana agama serta persoalan hidup yang sangat kompleks yang tidak dapat diatasi oleh ajaran agama, lalu kemudian sedikit demisedikit membentuk aliran baru berupa aliran kepercayaan yang pada mulanya menyerempet kepada ajaran Islam. Munculnya berbagai aliran sampalan ini j uga diakibatkan oleh lemehnya pengetahuan dasar Ilmu Keislaman (ushuluddin), dimana mereka yang membuat aliran ini biasanya menggunakan pendekatan rasio, dan kepentingan sesaat dari nilai agama yang mereka gunakan.

3. Sikap Mental Pesimis, Aparkis Dan A-Moral

Masa kini aktivitas internetan dan facebook telah merambah jauh kewilayah pemikiran, nafsu dan hati manusia, lewat sarana ini mulai mengganggu semangat kerja seseorang, menusuk jiwa anggota rumahtangga sehingga banyak terjadi aktivitas Cinta yang berujung kepada selingkuh, hubungan intim dan dapat merusak rumah tangga orang lain. Bagi generasi muda Indonesia saat ini kegiatan internetan dan facebook dimanfaatkan sebagai sumber pengetahuan da rujukan ilmiah dalam studinya. Tetapi efek negatifnya sangat besar bagi kualitas hidup para remaja.

C. Pentingnya Akidah Di Era Globalisasi

Individu yang dikatakan memiliki akhlak baik adalah individu yang siap bertanggung jawab atas setiap keputusan yang diperbuatnya. Pendidikan akhlak pun dapat dimaknai sebagai pendidikan yang mengedepankan nilai, budi pekerti, akhlak, moral, maupun watak, yang pada akhirnya memiliki tujuan untuk menumbuhkembangkan keterampilan peserta didik untuk menentukan keputusan baik-buruk, memelihara apa yang baik menghindari dan menjauhi apa 
yang dianggap buruk dan merugikan, mewujudkan, dan menebar kebaikan.

Pendidikan akhlak ditujukan sebagai bentuk upaya menunjang pembangunan Sumber Daya Manusia (SDM). Penekananya lebih pada bagaimana semua elemen individu maupun masyarakat secara umum mampu memahami pentingnya akhlak sebagai energi positif di semua aspek kehidupan, baik bersifat privat maupun ranah publik. Upaya meningkatkan pemahaman pendidika akhlak secara umum dalam hal ini akan ditinjau dari kacamata pendidikan akhlak sudut pandang Islam yang dalam hal ini berpedoman kepada al-Qur'an dan Hadits.

Berbagai macam tantangan di era globalisasi banyak menjadi penyebab menurunya akhlak.Menurut Marzuki adapun perilaku anti karakter bangsa di antaranya ditunjukkan oleh hilangnya nilai-nilai luhur yang melekat pada bangsa Indonesia, seperti kejujuran, kesantunan, dan kebersamaan, serta ditandai dengan munculnya berbagai kasus criminal.

Oleh karena itu pengembangan nilai pendidikan agama islam menjadi acuan yang utama tujuan untuk membentuk akhlak bangsa. Berbagai macam tantangan tersebut menuntut para penglola lembaga pendidikan, terutama lembaga pendidi kan Islam untuk melakukan perenugan dan penelitian kembali apa yang harus diperbuat dalam mengantisipasi tantangan tersebut, modelmodel pendidikan Islam seperti apa yang perlu ditawarkan di masa depan, yang sekiranya mampu mencegah dan atau mengatasi tantangan tersebut.

Pembahasan Pendidikan akhlak sebagai upaya pembentukan manusiamanusia dengan nilai luhur sepertinya menarik untuk terus dipelajari. Karena keberlangsungan suatu bangsa yang berdaulat akan dilihat dari seberapa baik 
warga negaranya menjalankan nilai nilai agamanya. Oleh karena itu penulis tertarik mengkaji pembahasan terkait pendidikan akhlak di era globalisasi.

Kemajuan teknologi informasi akhir ini hampir merubah tatanan pola pikir bagi masyarakat, baik dari anak-anak, remaja orang tua, juga mulai dari kalangan menengah sampai dengan kalangan atas. Era globalisasi zaman now dan gaya hidup (lifestyle) menjadi dampak dari arus globalisasi yang sudah tidak bisa dibendung lagi. Modernisasi di segala bidang telah menjadi bagian yang tak terpisahkan dari kehidupan masyarakat, seolah-olah berbagai alat teknologi tinggi menjadi bagian penting dalam kehidupan.

Berbagai penelitian tentang dampak dan pemanfaatan internet menurut Severin dan Tankard mengungkapkan Sejumlah penelitian tentang dampak dan pemanfaatan internet menunjukkan bahwa internet menjadi sumber utama untuk belajar tentang apa yang sedang terjadi di dunia seperti untuk hiburan, bergembira, relaksasi, untuk melupakan masalah, menghilangkan kesepian, untuk mengisi waktu sebagai kebiasaan dan melakukan sesuatu dengan teman atau keluarga

Kecanggihan dalam mengakses informasi melalui teknologi tersebut membutuhkan respon yang proaktif untuk memfilter terjadinya penurunan nilainilai akhlak masyarakat. Jika hal ini tidak dilakukan akan menimbulkan dampak buruk bagi masyarakat, seperti terjadinya criminal social seperti pelecehan seksual, anak melawan terhadap orang tua, siswa menganiaya guru. Faktor yang melatar belakangi terjadinya kenakalan remaja dapat dikelompokkan menjadi faktor internal dan faktor eksternal. Faktor internal berupa krisis identitas dan 
kontrol diri yang lemah. Sedangkan faktor eksternal berupa kurangnya perhatiannya dari Orangorang tua; minimnya pemahaman tentang keagamaan; pengaruh dari lingkungan sekitar dan pengaruh budaya barat serta pergaulan dengan teman sebaya; dan tempat pendidikan.

Konsep pendidikan akhlak didalam Islam memandang bahwa manusia dilahirkan dengan membawa potensi lahiriah yaitu:1) Potensi berbuat baik terhadap alam, 2) Potensi berbuat kerusakan terhadap alam, 3) Potensi ketuhanan yang memiliki fungsifungsi nonfisik. Ketiga potensi tersebut kemudian diserahkan kembali perkembangannya kepada manusia. Hal ini yang kemudian memunculkan konsep pendekatan yang menyeluruh dalam pendidikan Islam yaitu meliputi unsur pengetahuan, akhlak dan akidah. 
BAB III

\section{PENUTUP}

\section{A. Kesimpulan}

Globalisasi adalah proses mendunianya suatu hal sehingga batas antara negara menjadi hilang. Globalisasi didukung oleh berbagai faktor, seperti perkembangan teknologi, transportasi, ilmu pengetahuan, telekomunikasi, dan sebagainya yang lemudian berpengaruh pada perubahan berbagai aspek kehidupan dalam masyarakat.

Pendidikan akhlak merupakan solusi dalam menyelesaikan setiap permasalahan yang ada di dalam masyarakat terutama untuk menahan arus globalisasi yang negatif terutama budaya-budaya barat penerapan pendidikan akhlak pun tidak hanya dipahami dari satu sudut pandang saja namun juga dapat dikaji dari berbagai sudut.

B. Saran

Adapun saran dari pembahasan diatas yaitu alangkah baiknya kita sebagai penerus senantiasa memperbaiki akhlak akidah kita. 
DAFTAR PUSTAKA

Wahyudi, Dedi. 2017. Pengantar Akidah Akhlak dan Pembelajarannya. Yogyakarta: Lintas Rasi Aksra Books.

Hidayat, R. (2021). KONSEP PENDIDIKAN AKHLAK DI ERA GLOBALISASI. 